\title{
PLASMA AND SERUM PROTEINS IN CHRONIC RHEUMATIC DISEASES
}

\author{
BY \\ HAROLD B. SALT \\ From the Biochemical Laboratory, The Royal Infirmary, Worcester
}

From a study of the abnormal serum protein patterns which are characteristic of rheumatoid arthritis, Wallis (1950) has concluded that the hyperglobulinaemia is the result of the combined effects of inflammation, tissue destruction, and immunization, the last being the principal contributor in all but the early stages of the disease. His technique for protein investigations included a preliminary determination of serum albumin/globulin ratios by sodium sulphate fractionation, followed by electrophoretic and immunological studies of the sera from selected patients in whom the $A / G$ ratios had been found to be low.

This work, with previous studies of a similar nature by many other investigators (reviewed by Gutman, 1948), has shown that changes in the serum proteins in rheumatoid arthritis characteristically lead to a decrease in albumin and an increase in globulin. There is also an increase in plasma fibrinogen. The increase in globulin is due chiefly to increments in the alpha- and gamma- fractions, of an extent and proportion referable to the stage of the disease, although the bulk of the il crease cannot be accounted for by the development of specific antibodies.

The complex techniques used in these researches are too elaborate for routine use in the clinical laboratory. For simplicity, many workers have adopted indirect methods for assessing protein changes in the plasma or serum of rheumatic patients.

The plasma viscosity test (surveyed by Houston and others, 1949) yields information concerning the plasma proteins by providing an integral measure of their molecular asymmetry. In this respect, the large prolate spheroid molecules of fibrinogen contribute principally, while other asymmetric molecules exert an additional, though smaller, effect. The measurement of serum viscosity does not appear to have been adopted as a clinical test method, except for its use by Lawrence (1949) as part of his elaborate differential plasma viscosity test.

The erythrocyte sedimentation test has been interpreted in terms of plasma proteins through electrophoretic and other investigations. These have been summarized by Gutman (1948) and by Marrack and Hoch (1949) with the conclusion that, in chronic diseases, rapid sedimentation results chiefly from an increase in plasma fibrinogen and a decrease in albumin.

The serum thymol turbidity test, shown by Carter and Maclagan (1946) to be useful in studying rheumatoid arthritis, yields results in this type of disease 
which are apparently due to an increase in serum gamma-globulin and a decrease in albumin (Marrack and Hoch, 1949; Marrack and others, 1950).

The thymol turbidity test has been studied in various diseases by Dreyfuss (1948) in parallel with a serum dilution turbidity test, with the conclusion that the two tests yield results which are closely similar and that they probably depend upon similar deviations in serum protein patterns. Both positive thymol turbidity and positive dilution turbidity tests were noted by Dreyfuss in patients with rheumatoid arthritis.

\section{Present Investigations}

The aim of the investigations presently described was to demonstrate that quick and simple methods for fractionation and chemical determination of plasma proteins can provide useful information in the routine study of chronic rheumatic conditions. Since an increment in the globulin moiety appears.to be the most dependable feature of the altered protein patterns found in such conditions, this fraction was chosen as a basis for the grouping of the analytical results. The indirect tests mentioned above were also adopted in the investigations with the purpose of assessing their value as indicators of protein abnormalities.

Analytical data were recorded in three groups for blood samples from 152 patients whose conditions included sub-acute (active) and chronic (inactive) rheumatoid artbritis, osteo-arthritis, and fibrositis.

\section{Analytical Methods}

The estimations of plasma total protein, of plasma globulin (including fibrinogen), and of serum globulin, recorded in Table $I$, were made by the direct dispersimetric method of Salt (1950), in which the globulin is fractionated by methanol. Albumin values were obtained by difference between total protein and globulin.

In subsequent analyses (Tables II and III), the serum protein fractions were separated by means of sodium sulphite at concentrations of $15 \cdot 0,18 \cdot 0$ and $21 \cdot 0$ per cent., as described by Campbell and Hanna (1937). The protein concentrations in the sulphite filtrates and the total protein concentrations of saline-diluted sera were then each determined by an adaptation of the biuret reaction of Sunderman and Schmidt (1944), followed by absorptiometric measurements in the photelometer described by Salt (1950), with narrow waveband yellow-green light (Ilford filter No. 605). Using these procedures, accurate determinations were quickly completed and the various protein fractions were computed by differences.

Fibrinogen concentrations were estimated directly by micro-Kjeldahl digestion of the protein precipitated from plasma by $12 \cdot 5$ per cent. sodium sulphite (Campbell and Hanna, 1937), followed by nesslerization and absorptiometry, using spectral blue light (Ilford filter No. 602). All values for total protein and for protein fractions are given in $\mathrm{g}$. per $100 \mathrm{ml}$. serum or plasma.

Erythrocyte sedimentation tests were performed by the method of Collins and others (1939), and values were recorded as clear plasma per cent. by volume at one hour. The values were then adjusted to corrected sedimentation rates on the basis of erythrocyte packed-cell volume. Further details have been given by Arnold and Salt (1950), together with an estimate of the degree of correlation which exists between corrected sedimentation rate and plasma viscosity values.

Plasma or serum viscosity values were determined by the technique described by Woodmansey and Wilson (1948) and recorded in millipoise units. The technique is 
simple and is characterized by about the same degree of accuracy as the corrected sedimentation rate test (Dawson and Salt, 1950).

The thymol turbidity tests were carried out by the technique of Maclagan (1944), except that volumes of serum and reagent were doubled, and the dilution turbidity tests by the method of Dreyfuss (1948). The results in each case were determined by lightdispersion measurements in the photelometer (Salt, 1950) with spectral red light (Ilford filter No. 608), using standards prepared from known amounts of serum protein precipitated with salicylsulphonic acid. The results for each of the turbidity tests are recorded in Maclagan's arbitrary units.

\section{Results}

Table I presents a summary of the analytical results derived from the blood samples of 38 unselected patients, sixteen of whom yielded values for plasma globulin (including fibrinogen) of less than 3.0 per cent., and 22 values greater than 3.0 per cent. Mean values with standard deviations are shown for each subgroup, together with the values for $t$ and $P$ (Fisher, 1941) which furnish a statistical evaluation of the magnitude and significance of the differences between the means.

TABLE I

SUMMARY OF ANALYTICAL DATA FROM BLOOD SAMPLES OF 38 PATIENTS*

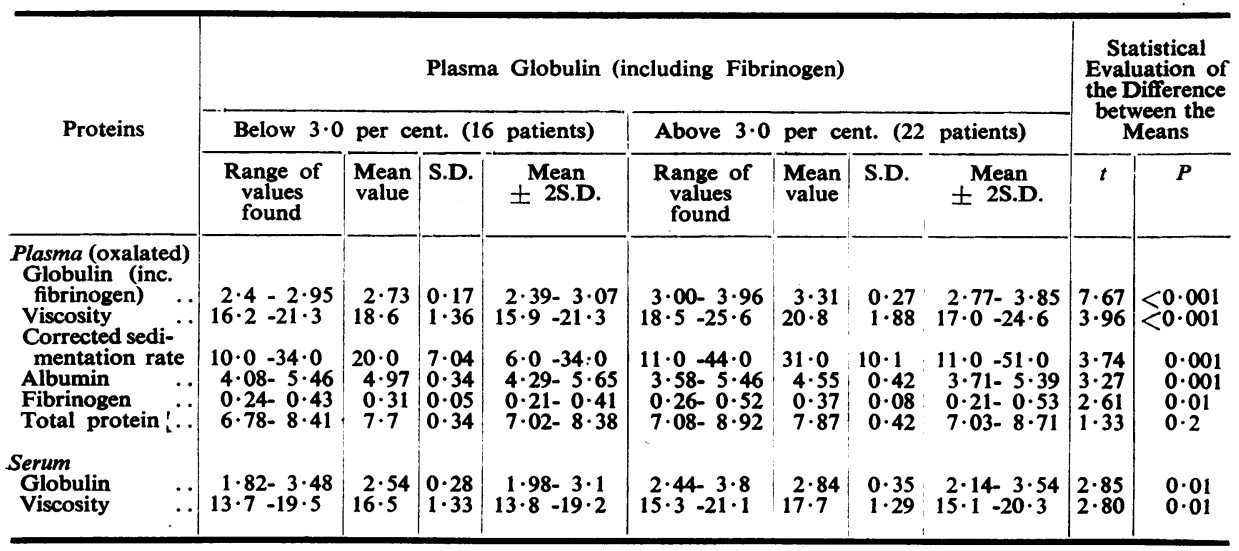

* Units of measurement given in text under " Analytical Methods".

The differences in plasma globulin (including fibrinogen) concentrations determined chemically, are seen to be closely paralleled by the values for plasma viscosity and for corrected sedimentation rate. A significant diminution in the albumin content of the plasma also accompanies the augmented globulin and fibrinogen levels, whereas the fibrinogen content differs only slightly in the two sub-groups. The mean values for plasma total protein concentrations do not differ significantly ( $P$ is greater than 0.05 ), probably because the series did not happen to include many of the more grossly abnormal plasmas. Significant differences for serum globulin concentrations and for serum viscosity values suggested the possibility that detailed analysis of serum might yield results of greater value than the analyses of plasma. 
TABLE II SUMMARY OF ANALYTICAL DATA FROM BLOOD SAMPLES OF 61 PATIENTS*

\begin{tabular}{|c|c|c|c|c|c|c|c|c|c|c|}
\hline \multirow[t]{2}{*}{ Proteins } & \multicolumn{4}{|r|}{ Serum } & \multicolumn{4}{|l|}{ Globulin } & \multicolumn{2}{|c|}{$\begin{array}{c}\text { Statistical } \\
\text { Evaluation of } \\
\text { the Difference } \\
\text { between the } \\
\text { Means }\end{array}$} \\
\hline & $\frac{\text { Below } 3 \cdot 0}{\begin{array}{c}\text { Range of } \\
\text { values } \\
\text { found }\end{array}}$ & $\begin{array}{l}\text { Mean } \\
\text { value }\end{array}$ & S.D. & $\begin{array}{c}\text { Mean } \\
\pm \quad 2 S . D .\end{array}$ & $\frac{\text { Above } 3 \cdot 0}{\begin{array}{l}\text { Range of } \\
\text { values } \\
\text { found }\end{array}}$ & $\begin{array}{l}\text { Mean } \\
\text { value }\end{array}$ & S.D. & $\begin{array}{c}\text { Mean } \\
\pm \quad \text { 2S.D. }\end{array}$ & $t$ & $P$ \\
\hline $\begin{array}{l}\text { Serum } \\
\text { Globulin } \\
\text { Total protein } \ldots \\
\text { Euglobulin } \\
\text { Pseudoglobulin I } \\
\text { Pseudoglobulin II } \\
\text { Albumin }\end{array}$ & $\begin{array}{l}1.91-2.95 \\
6.53-8.92 \\
0.6-1.98 \\
0.15-0.96 \\
0.19-0.97 \\
3.74-6.53\end{array}$ & $\begin{array}{l}2 \cdot 48 \\
7 \cdot 67 \\
1 \cdot 27 \\
0 \cdot 63 \\
0 \cdot 58 \\
5 \cdot 19\end{array}$ & $\begin{array}{l}0.3 \\
0.61 \\
0.34 \\
0.25 \\
0.21 \\
0.68\end{array}$ & $\begin{array}{l}1 \cdot 88-3 \cdot 08 \\
6 \cdot 45-8 \cdot 89 \\
0 \cdot 59-1.95 \\
0 \cdot 13-1 \cdot 13 \\
0 \cdot 16-1 \cdot 0 \\
3 \cdot 83-6 \cdot 55\end{array}$ & $\begin{array}{l}3 \cdot 04-5 \cdot 18 \\
7 \cdot 19-9 \cdot 73 \\
0 \cdot 94-3 \cdot 46 \\
0 \cdot 31-1 \cdot 66 \\
0 \cdot 22-1 \cdot 38 \\
3 \cdot 74-6 \cdot 2\end{array}$ & $\begin{array}{l}3 \cdot 7 \\
8 \cdot 57 \\
1 \cdot 97 \\
1 \cdot 0 \\
0 \cdot 74 \\
4 \cdot 87\end{array}$ & $\begin{array}{l}0.58 \\
0.62 \\
0.65 \\
0.32 \\
0.31 \\
0.37\end{array}$ & $\begin{array}{l}2 \cdot 54-4 \cdot 86 \\
7 \cdot 33-9 \cdot 81 \\
0 \cdot 67-3 \cdot 27 \\
0 \cdot 36-1 \cdot 64 \\
0 \cdot 12-1 \cdot 36 \\
4 \cdot 13-5 \cdot 61\end{array}$ & $\begin{array}{l}9 \cdot 6 \\
5 \cdot 61 \\
4 \cdot 98 \\
4 \cdot 9 \\
2 \cdot 28 \\
2 \cdot 12\end{array}$ & $\begin{array}{c}<0.001 \\
<0.001 \\
<0.001 \\
<0.001 \\
0.02 \\
0.05\end{array}$ \\
\hline $\begin{array}{c}\text { Plasma (oxalated) } \\
\text { Corrected sedi- } \\
\text { mentation rate } \\
\text { Fibrinogen }\end{array}$ & $\begin{array}{l}0.0-47 \cdot 0 \\
0.24-0.8\end{array}$ & $\begin{array}{c}23 \cdot 0 \\
0.41\end{array}$ & $\begin{array}{c}14 \cdot 7 \\
0 \cdot 13\end{array}$ & $\begin{array}{c}(6) \dagger-52.0 \\
0 \cdot 15-0.67\end{array}$ & $\begin{array}{l}7 \cdot 0-47 \cdot 0 \\
0 \cdot 18-0 \cdot 96\end{array}$ & $\begin{array}{c}37 \cdot 0 \\
0 \cdot 51\end{array}$ & $\begin{array}{r}10 \cdot 57 \\
0 \cdot 16\end{array}$ & $\begin{array}{c}16 \cdot 0-58 \cdot 0 \\
0 \cdot 19-0.83\end{array}$ & $\begin{array}{l}4 \cdot 32 \\
2 \cdot 56\end{array}$ & $\begin{array}{c}<0.001 \\
0.01\end{array}$ \\
\hline
\end{tabular}

Table II contains a summary of the analytical results derived from the blood samples of a further 61 patients, 2.5 of whom yielded values for serum globulin of less than 3.0 per cent. and 36 values greater than 3.0 per cent.

Differences in the serum globulin concentrations are evident also in the values for serum total protein; and of the globulin fractions, increments in the euglobulin and pseudoglobulin I components are those which contribute principally to globulin increases. Serum albumin shows a small (just significant) difference, opposite in direction to the globulin differences. The corrected sedimentation rate values, which may be held to indicate abnormalities of plasma protein structure, also show differences in this series corresponding to the differences in serum globulins, whereas the plasma fibrinogen concentrations show only slight differences.

TABLE III

SUMMARY OF ANALYTICAL DATA FROM BLOOD SAMPLES OF 53 PATIENTS*

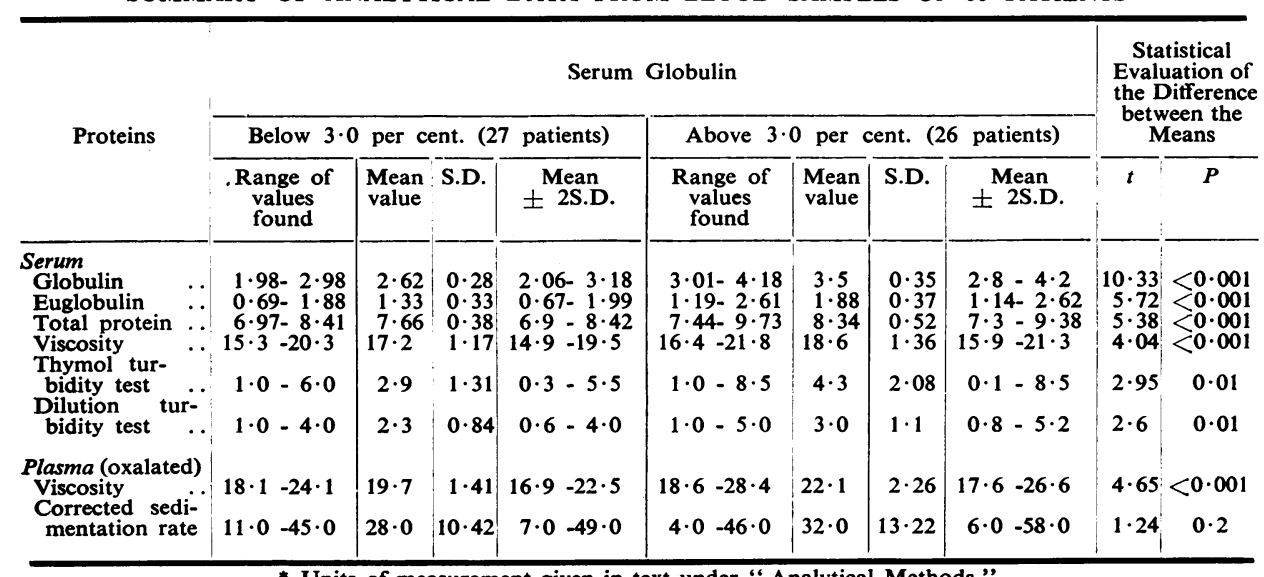

* Units of measurement given in text under "Analytical Methods".

A third series of analytical results is summarized in Table III. These were 
derived from the blood samples of a further 53 patients, who were sub-divided in the same way as the previous series, 27 patients having serum globulin levels below 3.0 per cent., and 26 patients levels above 3.0 per cent. The analytical methods chosen for this series included three indirect serum protein tests and two indirect plasma protein tests, as well as estimations of serum euglobulin and total protein concentrations.

The differences in the sub-groups based on serum globulin concentrations are demonstrated also by the euglobulin and total protein values in a manner very - similar to that seen in the previous experiments of Table II, and the serum viscosity values likewise afford a similar means of differentiation. The significance of the plasma viscosity values appears to correspond closely to that of the serum viscosity values, but in this series the corrected sedimentation rates do not differ significantly in the two sub-groups $(P$ is less than 0.05$)$. The thymol turbidity and dilution turbidity tests appear to be of only moderate value as indicators of hyperglobulinaemia.

In order to compare the value of the different tests, the data summarized in Table III were re-arranged in five groups, based on ranges of serum globulin concentration, and mean values were calculated for each group (Table IV). It is evident that each type of analysis shows the same general trend of values corresponding with the gradation of serum globulin, but that the tests vary in their degree of correspondence. As indicators of hyperglobulinaemia, the thymol turbidity and dilution turbidity tests appear to be less sensitive than the serum viscosity or plasma viscosity values, and the corrected sedimentation rate (in this series) is the least sensitive of the tests.

TABLE IV

ANALYTICAL VALUES FROM 53 PATIENTS, BY SERUM GLOBULIN*

\begin{tabular}{|c|c|c|c|c|c|c|c|c|}
\hline \multirow{3}{*}{$\begin{array}{l}\text { No. of } \\
\text { Analyses }\end{array}$} & \multirow{3}{*}{$\begin{array}{c}\text { Range of Serum } \\
\text { Globulin } \\
\text { Concentration }\end{array}$} & \multicolumn{7}{|c|}{ Mean Values of Corresponding Analyses } \\
\hline & & \multicolumn{4}{|c|}{ Serum } & & \multicolumn{2}{|c|}{ Plasma } \\
\hline & & $\underset{\substack{\text { Euglobu- } \\
\text { lin }}}{ }$ & $\underset{\text { protein }}{\text { Total }}$ & Viscosity & $\begin{array}{c}\text { Thymol } \\
\text { turbidity } \\
\text { test }\end{array}$ & $\begin{array}{c}\text { Dilution } \\
\text { turbidity } \\
\text { test }\end{array}$ & Viscosity & $\begin{array}{c}\text { Corrected } \\
\text { sedimenta- } \\
\text { tion rate }\end{array}$ \\
\hline $\begin{array}{r}9 \\
18 \\
14 \\
9 \\
3\end{array}$ & $\begin{array}{l}2 \cdot 0-2 \cdot 5 \\
2 \cdot 5-3 \cdot 0 \\
3 \cdot 0-3 \cdot 5 \\
3 \cdot 5-4 \cdot 0 \\
4 \cdot 0-4 \cdot 5\end{array}$ & $\begin{array}{l}1 \cdot 1 \\
1 \cdot 45 \\
1 \cdot 7 \\
2 \cdot 0 \\
2 \cdot 35\end{array}$ & $\begin{array}{l}7 \cdot 54 \\
7 \cdot 71 \\
8 \cdot 13 \\
8 \cdot 41 \\
9 \cdot 11\end{array}$ & $\begin{array}{l}16 \cdot 7 \\
17 \cdot 5 \\
18 \cdot 1 \\
19 \cdot 1 \\
19 \cdot 2\end{array}$ & $\begin{array}{l}2 \cdot 7 \\
3 \cdot 0 \\
3 \cdot 7 \\
4 \cdot 4 \\
6 \cdot 2\end{array}$ & $\begin{array}{l}2 \cdot 1 \\
2 \cdot 7 \\
2 \cdot 7 \\
3 \cdot 2 \\
3 \cdot 8\end{array}$ & $\begin{array}{l}19 \cdot 2 \\
19 \cdot 9 \\
21 \cdot 4 \\
22 \cdot 4 \\
24 \cdot 2\end{array}$ & $\begin{array}{l}26 \\
28 \\
29 \\
32 \\
44\end{array}$ \\
\hline
\end{tabular}

* Units of measurement given in text under "Analytical Methods".

\section{Conclusions}

As a general conclusion from the experiments, it appears evident that the hyperglobulinaemia demonstrable in patients with chronic rheumatic disease is due chiefly to increments in the euglobulin and pseudoglobulin I fractions, which can be evaluated by simple chemical analysis. Serum total protein concentrations may also be increased because of the hyperglobulinaemia, but the increment may be partially off-set by a depletion in the albumin component. Variations in plasma fibrinogen concentration do not necessarily parallel those in serum globulin, 
so that the estimation of fibrinogen and the measurement of plasma viscosity or corrected sedimentation rate, which appear to depend principally on fibrinogen, yield results only approximately related to the hyperglobulinaemia. Measurements of serum viscosity seem to merit further study, although the non-specific nature of this type of test suggests that direct determinations of serum globulin or euglobulin are to be preferred. The methods which have been used in the present experiments are recommended for ease and precision; further work is in progress with the purpose of improving them yet further. It should be noted that the protein fractions, apart from plasma fibrinogen, are determined most successfully by the use of samples of serum.

\section{Discussion}

The abnormalities of individual protein fractions and the changes in the results of empirical tests are alike unrelated specifically to chronic rheumatic disease. The use of empirical tests has developed after the classical precedent of the determination of erythrocyte sedimentation rate, and many such tests are now in use. Often these have the advantages of speed, simplicity, and clinical signification, but they vary in sensitivity and in their applicability to different problems arising in the laboratory -study of diseases. In chronic rheumatic diseases, Carter and Maclagan (1946) found the serum colloidal gold test to be more sensitive than the thymol turbidity test. Fraser (1948) further studied the colloidal gold test and found the cephalin-cholesterol flocculation test of little value in rheumatoid arthritis. In the present studies, the thymol turbidity test was adopted because the turbidity measured is largely due to precipitated gamma-globulin; and the dilution turbidity test was chosen because it forms a measure of serum beta-lipoprotein and gamma-globulin.

Lawrence (1949) has developed an elaborate differential plasma viscosity test for the purpose of delineating plasma protein patterns. Although this appears to be superior to simple determinations of plasma or serum viscosity, it would seem more appropriate to adopt methods involving separation and direct estimation of the plasma protein components. Mester (1945) has advocated the determination of plasma fibrinogen in addition to the sedimentation rate, and Davis (1936) has made detailed analyses of the plasma protein fractions in arthritis, with results very similar to those of the present experiments. As the analytical methods now available are comparably precise but much less laborious than those used by Davis, and since the various empirical tests have largely been interpreted in terms of protein changes, the direct determinations of protein fractions which could replace the empirical tests with advantage, are to be recommended.

\section{Sumnary}

(1) Changes in the pattern of plasma and serum proteins which may develop in chronic rheumatic conditions and their delineation by various direct methods and by certain indirect empirical tests are considered. It is recognized that none of these changes is specifically related to rheumatic disease. 
(2) A summary of the analytical data recorded for blood samples from 152 patients is presented in four Tables, together with statistical evaluations. The data include values for plasma or serum total protein, total globulin fractionated by methanol, euglobulin and pseudoglobulins I and II fractionated by different concentrations of sodium sulphite, albumin, and fibrinogen, together with corrected sedimentation rates, viscosity measurements, and the results of thymol turbidity and dilution turbidity tests. The grouped data are classified according to the presence or absence of hyperglobulinaemia.

(3) It is shown that hyperglobulinaemia is chiefly due to increments in the euglobulin and pseudoglobulin I fractions. . These increments can be demonstrated readily by precise but simple chemical determinations.

(4) Various empirical tests which have been advocated for the laboratory study of chronic rheumatism are discussed. Such tests vary in sensitivity and in the nature of the plasma or serum abnormalities indicated. It is concluded that empirical tests could be replaced with advantage by direct determinations of plasma or serum protein components.

I wish to thank Dr. H. L. Milles and Dr. J. E. Dawson for their co-operation in providing access to their patients; and Miss P. Arnold for performing many of the analyses.

\section{REFERENCES}

Arnold, P., and Salt, H. B. (1950). Bull. Inst. med. Lab. Tech., 15, 3.

Campbell, W. R., and Hanna, M. I. (1937). J. biol. Chem., 119, 15.

Carter, A. B., and Maclagan, N. F. (1946). Brit. med. J., 2, 80.

Collins, D. H., Gibson, H. J., Race, J., and Sălt, H. B. (1939). Annals of the Rheumatic Diseases, 1, 333.

Davis, J. S., Jr. (1936). J. Lab. clin. Med., 21, 478.

Dawson, J. E., and Salt, H. B. (1950). Brit. J. phys. Med., 13, 152.

Dreyfuss, F. (1948). J. Lab. clin. Med., 33, 672.

Fisher, R. A. (1941). " "Statistical Methods for Research Workers ”, 8th ed., p. 120. Oliver and Boyd, London.

Fraser, T. N. (1948). Annals of the Rheumatic Diseases, 7, 83.

Gutman, A. B. (1948). Advanc. protein Chem., 4, 155.

Houston, J., Whittington, R. B., Cowan, I. C., and Harkness, J. (1949). J. clin. Invest., $28,752$.

Lawrence, J. S. (1949). Annals of the Rheumatic Diseases, 8, 209.

Maclagan, N. F. (1944). Brit. J. exp. Path., 25, 234.

Marrack, J. R., and Hoch, H. (1949). J. clin. Path., 2, 161.

, Johns, R. G. S., and Hoch, H. (1950). Brit. J. exp. Path., 31, 36.

Mester, A. J. (1945). Annals of the Rheumatic Diseases, 4, 57.

Salt, H. B. (1950). J. Lab. clin. Med., 35, 976.

Sunderman, F. W., and Schmidt, P. (1944). Amer. J. clin. Path., 14, Tech. Sect. 8, 47.

Wallis, A. D. (1950). Ann. intern. Med., 32, 63.

Woodmansey, A., and Wilson, J. V. (1948). Annals of the Rheumatic Diseases, 7, 235.

\section{Protéines du Plasma et du Sérum dans les Maladies Rhumatismales Chroniques}

\section{RÉSUMÉ}

(1) L'auteur étudie les modifications du taux des protéines du plasma et du sérum survenant au cours des maladies rhumatismales chroniques ainsi que les méthodes directes et indirectes ou empiriques par lesquelles ce taux est déterminé. Il est entendu qu'aucune de ces modifications ne se rapporte spécifiquement à la maladie rhumatismale.

(2) Quatre tableaux présentent un résumé des données de l'examen du sang de 152 malades, ainsi que l'évaluation statistique de ces données. Ces déterminations quantitatives portent sur: protéines totales du plasma et du sérum, globuline totale fraccionnée au méthanol, euglobuline et pseudoglobuline I et II fraccionnées en concentrations différentes de sulfite de soude, albumine, 
fibrinogène, sédimentation globulaire corrigée, turbidité au thymol et turbidité en dilution. Dans chaque tableau le groupement des résultats est déterminé par la présence ou par l'absence de l'hyperglobulinémie.

(3) L'hyperglobulinémie est due surtout à l'augmentation du taux de l'euglobuline et de la pseudoglobuline I. Cette augmentation peut être démontrée facilement par des analyses chimiques simples mais précises.

(4) L'auteur discute les différentes méthodes empiriques recommandées pour l'étude de laboratoire du rhumatisme chronique. La sensibilité de ces méthodes est variable et les résultats n'indiquent pas la nature des anomalies des protéines sanguines. L'auteur conclut qu'il y aurait avantage à remplacer les méthodes empiriques par des analyses directes des protéines du plasma et du sérum.

\section{Proteinas del Plasma y del Suero en las Enfermedades Reumàticas Crónicas}

\section{RESUMEN}

(1) El autor estudia las alteraciones de los valores de las proteinas del plasma y del suero en el curso de las enfermedades reumáticas crónicas así como los méthodos, directos e indirectos o empíricos, de determinación de estos valores. Reconoce que estas alteraciones no tienen carácter específico en la enfermedad reumática.

(2) Cuatro cuadros presentan el resumen de los datos obtenidos al analizar la sangre de 152 enfermos, así como la valuación estadística de estos datos. Se determinaron: proteinas totales del plasma y del suero, globulina total fraccionada por metanol, euglobulina y pseudoglobulina I y II fraccionadas por varias concentraciones de sulfito de sodio, albumina, fibrinogeno, sedimentación globular corregida, turbiedad al timol y turbiedad en dilución. En los cuadros la agrupación de los resultados fué determinada por la existencia o la ausencia de la hiperglobulinemia.

(3) La hiperglobulinemia se debe principalmente al aumento de la euglobulina y de la pseudoglobulina I. Este aumento se puede demostrar fácilmente por análisis químicos simples, pero precisos.

(4) El autor discute los varios métodos empíricos propugnados para el estudio de laboratorio del reumatismo crónico. La sensibilidad de estos métodos es variable y sus resultados no indican la naturaleza de las abnormalidades de las proteinas sanguineas. Conclude que habría ventaja en sustituir los métodos empíricos por análisis directos de las proteinas del plasma y del suero. 